\title{
APLIKASI LIMBAH TERNAK SEBAGAI SUMBER MIKROBA UNTUK FERMENTASI SILASE DIKELOMPOK TANI RANCAMULYA SUMEDANG
}

\author{
Eulis Tanti Marlina, Deden Zamzam Badruzzaman, dan Hendi Setiyatwan \\ Fakultas Peternakan Universitas Padjadjaran Jl. Raya Sumedang-Jatinangor Tlp. (022)7798241 Jatinangor 45363 \\ E-mail: eulis.tanti@unpad.ac.id
}

\begin{abstract}
ABSTRAK. Limbah peternakan mengandung beragam mikroba pengurai bahan organik. Mikroba asal limbah ternak dapat dimanfaatkan dalam proses pembuatan silase untuk mempersingkat waktu inkubasi dengan produksi silase yang berkualitas baik. Pada umumnya peternak akan kesulitan mendapatkan hijauan pakan ternak pada musim kemarau. Seringkali ternak diberi pakan seadanya dengan kualitas dan kuantitas yang tidak memadai. Tujuan penyuluhan ini merupakan difusi inovasi pembuatan silase pada masyarakat peternak di kelompok tani Rancamulya dengan memanfaatkan limbah ternak sebagai konsorsium mikroba starter. Melalui difusi inovasi pembuatan silase diharapkan dapat meningkatkan pengetahuan dan keterampilan peternak dalam membuat silase dengan memanfaatkan jumlah hijauan pakan ternak pada saat produksi melimpah. Metode yang digunakan dalam difusi inovasi ini adalah penyuluhan secara langsung (Direct Communication) dan metode demonstrasi melalui demonstrasi plot pembuatan starter dan silase serta pengawetan beberapa bahan pakan. Hasil difusi inovasi silase menggunakan starter mikroba asal limbah ternak pada masyarakat peternak Desa Rancamulya Sumedang menghasilkan peningkatan pengetahuan tentang teknologi pengolahan limbah dan teknologi silase dengan peningkatan pengetahuan mencapai 3,82 \% pada materi pengolahan limbah dan 99,42\% pada materi teknologi silase. Peran serta masyarakat dalam proses difusi inovasi cukup responsif. Demikian juga partisipasi aparat desa dan Petugas Penyuluh Lapangan (PPL) Kecamatan Sumedang Utara cukup baik sehingga diharapkan dapat menularkan semangant transferteknologi tepat guna yang lebih luas.
\end{abstract}

Kata Kunci: Mikroba asal limbah ternak; silase; pengawetan hijauan

\section{APPLICATION OF ANIMAL WASTE AS MICROBIC SOURCE FOR SILASE FERMENTATION IN RANCAMULYA SUMEDANG FARMERS}

ABSTRACT. Livestock waste contains a variety of microbes which decompose organic matter. Microbes from livestock waste can be utilized in the process of making silage to shorten the incubation time with good quality silage production. In general, farmers will find it difficult to get fodder during the dry season. Often livestock are given makeshift feed with inadequate quality and quantity. The purpose of this extension is the diffusion of innovation in making silage in Rancamulya farmer groups by utilizing livestock waste as a consortium of starter microbes. It is hoped that through the diffusion of innovations in making silage, it will increase the knowledge and skills of farmers in making silage by utilizing the amount of forage in abundant production. The method used in this diffusion of innovations is direct communication and demonstration methods through demonstration plots for making starters and silage and preservation of some feed ingredients. The results of silage innovation diffusion using microbial starters from livestock waste in the farmers community in Rancamulya Village, Sumedang resulted in increased knowledge about waste processing technology and silage technology with increased knowledge reaching $3.82 \%$ in waste treatment and $99.42 \%$ in silage technology. Community participation in the diffusion process of innovation is quite responsive. Likewise, the participation of village officials and Field Extension Officers of North Sumedang District was good enough that it was expected to be able to transmit employees to a wider range of appropriate technologies.

Key words: Microbes from livestock waste; silage; forage preservation

\section{PENDAHULUAN}

Usaha peternakan merupakan bagian yang tidak terpisahkan dalam perekonomian masyarakat pedesaan. Walaupun dalam skala usaha kecil, diharapkan usaha peternakan dapat menopang system perekonomian pedesaan melalui efisiensi usaha. Desa Rancamulya merupakan salah satu desa di Kecamatan Sumedang Utara Kabupaten Sumedang Jawa Barat mempunyai luas wilayah 252,05 Ha dengan jumlah penduduk 7.333 jiwa (Direktorat Pemberdayaan Masyarakat Desa Departemen Dalam Negeri, 2014). Peruntukan lahan untuk lahan pertanian mencapai 102,31 Ha atau 40,6\% total wilayah. Masyarakat Desa Rancamulya sebagian besar bekerja sebagai petani. Namun demikian, hampir sebagian besar petani di Desa Rancamulya juga sebagai peternak. Ternak yang dipelihara cukup beragam, dari mulai unggas (ayam broiler, ayam buras, bebek), ternak ruminansia kecil (kambing dan domba), ternak ruminansia besar (sapi potong, sapi perah, kerbau), serta ternak kuda (Tabel 1). Ternak sudah dipelihara secara intensif namun dengan dengan system perkandangan yang masih sederhana serta pemberian pakan yang seadanya. Sistem peternakan intensif akan menghasilkan terkonsentrasinya limbah di 
suatu tempat. Pengelolaan limbah ternak sudah dilakukan secara sederhana dengan pembuatan kompos dan sebagian sudah ada yang mempraktekkan menjadi pupuk cair.

Lahan pertanian di Desa Rancamulya sebagian besar ditanami dengan padi dan palawija seperti tanaman jagung. Pada waktu panen tiba, seringkali jerami yang dihasilkan melimpah sehingga sebagian diberikan kepada ternak peliharaan dan sebagian lagi dibuang di lahan pertanian. Sementara itu, pada musim kemarau, ternak diberi pakan hijauan seadanya bahkan tidak jarang peternak harus mengeluarkan dana tambahan untuk membeli rumput yang didatangkan dari luar wilayah Sumedang. Dengan demikian ternak menjadi kurang terpenuhi jumlah dan kecukupan nilai nutrisinya akibat diskontinyuitas penyediaan pakan sepanjang tahun. Permasalahan seperti ini memberikan gambaran pentingnya masyarakat peternak dibekali pengetahuan yang memadai dalam teknologi pengawetan pakan hijauan ternak sehingga pergantian musim tidak menjadi masalah dalam menyediakan pakan yang berkualitas bagi ternaknya.

Salah satu teknologi pengawetan hijauan pakan ternak adalah teknologi silase. Silase adalah pakan yang telah diawetkan yang diproses dari bahan baku berupa tanaman hijauan, limbah pertanian, serta bahan pakan lainnya seperti ampas tahu, memanfaatkan bakteri pengurai yang menghasilkan asam laktat secara anaerob sampai dicapai pH 4-4,5 (McDonald dkk., 1991; Bolsen dkk., 2000, Balitbangtan, 2003). Silase dibuat dari hijauan yang mempuntai kadar air 40-50\% (Utomo, 2012). Dengan teknlogi silase dimungkinkan untuk dapat mengurangi tenaga kerja dan kehilangan nutrisi melalui fermentasi anaerob (Schroeder, 2004). Produksi silase dapat disimpan dalam jangka waktu lama tanpa mengurangi nutrisi yang terkandung dalam bahan asal. Hal ini dapat menjadi solusi bagi peternak dalam menjaga pasokan pakan yang berkualitas baik untuk ternaknya.

Beberapa penelitian untuk meningkatkan nilai silase sudah banyak dilakukan, diantaranya dengan menambahkan starter berupa konsorsium bakteri pada proses fermentasi. (Rice et al., 1995; Moran \& Trowen, 1995; Tamada et al., 1999; Thalib, dkk., 2000). Salah satu sumber mikroba tersebut adalah berasal dari limbah ternak. Kemampuan peternak dalam menguasai teknologi silase diharapkan dapat meningkatkan produktivitas ternak yang dipeliharanya.

\section{METODE}

Metode yang digunakan dalam difusi inovasi adalah penyuluhansecara langsung (Direct Communication/Face to Face Communication) (Lionberger dan Gwin, 1982). Penyuluhan juga menggunakan metode demonstrasi, dengan mempraktekkan langsung teknologi pembuatan silase kepada anggota kelompok tani/ternak Rancamulya.

Materi penyuluhan dibuat dalam bentuk modul pelatihan dengan disusun menggunakan bahasa yang mudah dimengerti oleh petani/peternak. Materi pengolahan limbah ternak terpadu dijelaskan terlebih dahulu sampai mereka cukup mengerti. Setelah pemberian materi dilanjutkan dengan praktek secara langsung. Para anggota diberi kesempatan untuk mempraktekkan teori yang sudah disampaikan dengan bimbingan secara penuh dari para penyuluh. Hal ini dilakukan agar para peserta penyuluhan dapat berpartisipasi secara aktif. Diskusi secara terbuka dilakukan di sela-sela kegiatan praktek.

Penetapan waktu pelaksanaan penyuluhan dikomunikasikan dan dikompromikan bersama masyarakat sehingga diperoleh waktu pelaksanaan yang tidak mengganggu aktivitas masyarakat. Hal ini merupakan upaya untuk mendapatkan respon yang positif dari masyarakat untuk hadirdalam kegiatan penyuluhan. Penyuluhan dilaksanakan di balai pertemuan dan pelaksanaannya meliputi pre test dan post test, penyampaian materi, dan diskusi.

Untuk melihat perubahan kognisi pada peternak dilakukan pre test dan post test. Data pre test dan post test dianalisis melalui perhitungan rata-rata (means), yaitu: $\bar{X}=\frac{\Sigma X_{i}}{n}$

Untuk mengetahui simpangan baku menggunakan rumus : $\mathrm{S}=\sqrt{\frac{8\left(X_{i}-\bar{x}\right)^{2}}{n-1}}$

\section{HASIL DAN PEMBAHASAN}

Kegiatan penyuluhan Pemanfaatan limbah ternak sebagai sumber mikroba pada fermentasi silase dalam upaya menjaga pasokan pakan hijauan berkualiatas di kelompok tani Rancamulya Sumedang sudah dilaksanakan melalui kerjasama dengan Direktorat Jenderal Pendidikan Tinggi Kementerian Riset, Teknologi dan Pendidikan Tinggi melalui Program Kemitraan Masyarakat (PKM) Tahun 2018. Respon masyarakat peternak cukup baik. Nilaipre test tentang pengetahuan peternak terhadap pengolahan limbah ternak sudah cukup baik berkisar 81,19 , namun pengetahuan tentang teknologi silase masih rendahyaitu 43,10 (Tabel 2). Namun demikian, hasil post test menunjukkan peningkatan pengetahuan peternak tentang teknologi silase mencapai 99,42\%, sedangkan peningkatan pengetahuan peternak mengenai teknologi pengolahan limbah hanya 3,82\%. Hasil ini disebabkan karena teknologi pengolahan limbah secara terpadu dengan teknologi sederhana namun sangat efesien dalam pengelolaan limbah sudah pernah diperkenalkan dalam program Ipteks bagi Masyarakat pada Tahun 2016.

Tabel 1. Populasi ternak di wilayah Desa Rancamulya

\begin{tabular}{llc}
\hline No. & \multicolumn{1}{c}{ Jenis Ternak } & Jumlah (ekor) \\
\hline 1 & Ayam & 9.000 \\
2 & Itik & 190 \\
3 & Domba & 180 \\
4 & Sapi Perah & 42 \\
5 & Sapi Potong & 21 \\
5 & Kerbau & 5 \\
6 & Kuda & 51 \\
\hline
\end{tabular}

Sumber: MonografiDesaRancamulya, 2015 


\section{Pembuatan Konsorsium Bakteri Asal Limbah Ternak}

Sebelum dilakukan praktek teknologi silase terlebih dahulu peternak dibekali keterampilan untuk membuat starter berupa konsorsium bakteri asal limbah ternak, yang dikenal dengan sebutan probiotik. Materi kegiatan yang diberikan berupa teori $20 \%$ dan praktek $80 \%$. Dalam teori diperkenalkan macam limbah yang dihasilkan dari pedesaan, limbah yang dapat diolah menjadi probiotik serta dampak negatif dari limbah apabila tidak dikelola dengan benar. Selanjutnya dilakukan demonstrasi plot (demplot) dengan membuat starter asal limbah sapi potong. Dengan melaksanakan praktekpenjelasan teori lebih efektif diterima peserta. Praktek

meliputi pemilihan bahan organik, pencampuran bahan, menumpuk campuran substrat dalam karung urea melalui teknik injeksi oksigen menggunakan alat sederhana berupa tongkat, merapikan karung di tempat yang terlindungi dari cucuran hujan dan penguapan yang berlebihan, dan pengamatan suhu setiap hari. Proses dekomposisi dilakukan selama 1 minggu.Peternak mencatat suhu yang terbentuk selama proses dekomposisi. Suhu harian berkisar antara $30-53^{\circ} \mathrm{C}$ (Tabel 3).

Tabel 2. Tingkat pengetahuan anggota Kelompok Tani Rancamulya terhadap pengolahan limbah dan teknologi silase

\begin{tabular}{llcc}
\hline No. & \multicolumn{2}{c}{ Materi Pengolahan Limbah } & Materi Silase \\
\hline 1 & Pre Test & $81,19 \pm 10,79$ & $43,10 \pm 11,70$ \\
2 & Post Test & $84,29 \pm 10,50$ & $85,95 \pm$ \\
& & 9,34 \\
\hline
\end{tabular}

Keterangan: Jumlah responden 21 orang; Kisaran nilai: 0-10

Tabel 3. Suhu harian selama dekomposisi awal

\begin{tabular}{cccc}
\hline No. & $\begin{array}{c}\text { Waktu } \\
\text { Dekomposisi } \\
\text { (Hari ke-) }\end{array}$ & $\begin{array}{c}\text { Suhu Dekomposisi } \\
\left({ }^{\circ} \mathrm{C}\right)\end{array}$ & Keterangan \\
\hline 1 & 0 & 30 & \\
2 & 1 & 51 & \\
3 & 2 & 53 & \\
4 & 3 & 52 & \\
5 & 4 & 44 & Suhu ruang \\
6 & 5 & 32 & \\
7 & 6 & 30 & \\
8 & 7 & 29 & \\
\hline
\end{tabular}

Keterangan: Bahan organik yang digunakan: campuran feses sapi potong dan jerami padi

Suhu dekomposisi menggambarkan adanya pertumbuhan mikroba serta aktivitasnya dalam menguraikan bahan organik limbah ternak. Sesuai yang diharapkan suhu yang dicapai sekitar $50-60^{\circ} \mathrm{C}$. Tujuan proses dekomposisi awal adalah menumbuhkan mikroba pengurai dan mereduksi bakteri patogen yang terdapat dalam limbah ternak (Marlina dkk., 2015).
Setelah proses dekomposisi awal yang dilaksanakan selama 1 minggu selesai, dilakukan proses ekstraksi. Proses ektraksi dilakukan saat dekomposan sudah dianginangin selama 2 minggu sampai mencapai kadar air $\pm 20 \%$. Cairan atau filtrat yang diperoleh dalam proses ekstraksi diambil bagian yang sangat encer. Bagian yang pekat selanjutnya bisa diinkubasi untuk memperoleh pupuk organic cair. Selanjutnya filtrat encer ditambah dengan $5 \%$ molasses sebagai sumber energi siap pakai untuk membantu pertumbuhan mikroba, dan diinkubasi selama 2 minggu dengan kondisi fakultatif anaerob. Wadah yang digunakan untuk inkubasi menggunakan ember kapasitas 15 liter yang dilengkapi dengan penutup. Ember ditutup secara rapat menggunakan lakban agar hanya sedikit udara yang bisa masuk.

Probiotik dikatakan "matang" atau siap digunakan apabila dilakukan pemeriksaan secara organoleptic melalui pengamatan warna dan bau. Warna probiotik jernih kecoklatan disertai adanya butir butir halus berupa yeast, serta tercium bau asam menyegarkan, dengan $\mathrm{pH}$ yang terbentuk 4-4,5. Asam yang terbentuk berasal dari bakteri asam laktat yang menghasilkan asam laktat dengan ciri bau yang menyenangkan (Winarno, 2004; Surono, 2004). Keberadaan bakteri asam laktat pada starter merupakan salah satu jenis bakteri yang bermanfaat pada proses pembentukan asam pada fermentasi silase.

\section{Pembuatan Binder Menggunakan Dedak Padi}

Starter yang ditambahkan pada proses pembuatan silase, baik jerami jagung maupun jerami padi, pada konsentrasi yang sangat kecil, yakni $0,5 \%$. Oleh karena itu, untuk memudahkan dalam proses pencampuran starter dengan hijauan maka dilakukan upaya mengikat suspensi mikroba dalam suatu bahan yang disebut binder. Salah satu bahan yang dapat digunakan sebagai Binder atau bahan pengikat adalah dedak padi. Bahan pengikat dipilih dedak padi dengan pertimbangan bahan tersebut banyak tersedia dan mempunyai kandungan nutrisi yang cukup baik (Hadipernata, dkk., 2012). Molasses ditambahkan untuk kebutuhan energi siap pakai mikroba. Dedak padi difermentasi secara anaerob menggunakan tong plastic kapasitas 30 L selama 7 hari. Starter yang sudah dalam bentuk padat ini dapat disimpan lama dengan syarat disimpan dalam kondisi anaerob.

\section{Pembuatan Silase Hijauan Pakan Ternak}

Silase adalah pakan ternak yang di hasilkan melalui proses fermentasi hijauan segar yang mengandung kadar air tinggi (Bolsen dan Sapienza, 1993). Pemanfaatan hijauan pakan ternak yang melimpah pada saat musim hujan melalui pemanfaatkan teknologi sederhana yaitu dengan pembuatan silase, memberikan solusi tepat bagi peternak domba atau ruminansia lainnya guna menjamin ketersediaan pakan saat musim kemarau. Disamping itu, melalui pembuatan silase, hijauan yang dihasilkan telah mengalami perombakan komponen-komponen kompleksnya menjadi komponen- 
komponen yang lebih sederhana, sehinga mudah dicerna oleh mikroba rumen dan meningkatkan daya cerna serta efisiensi pakannya (Sutanto, 2000).

Penambahan berbagai macam substrat/aditif dimungkinkan dalam pembuatan silase. Secara umum, yang dimaksud dengan substrat/aditif dalam pembuatan silase adalah bahan yang dapat membantu ensilase, dengan berperan dalam mensuplai nutrien bagi bakteri asam laktat untuk memproduksi asam laktat, enzim atau mikroba yang dapat meningkatkan ketersediaan karbohidrat atau nutrien lain yang dibutuhkan bakteri pembentuk asam laktat.

Demplot dilaksanakan di tempat pertemuan gapoktan. Hijauan yang diperoleh berasal dari sisa panen jagung dan padi di sekitar Desa Rancamulya. Jerami jagung dan jerami padi dicacah menggunakan mesin pencacah untuk mendapat hasil cacahan yang rata $( \pm$ 3-4 cm) dan cepat. Proses silase bisa selesai selama 1-2 mggu, selanjutnya bahan pakan tersebut dapat disimpan lama untuk cadangan pakan saat kemarau dengan syarat silase dalam kondisi tertutup rapat (anaerob). Hambatan muncul disebabkan waktu pengabdian dilaksanakan pada musim kemarau Panjang sehingga peternak agak sulit menyediakan hijauan yang cukup banyak. Tujuan silase adalah pengawetan hijauan agar pada saat produksi hijauan melimpah dapat diawetkan dan digunakan pada saat produksi hijauan rendah (kemarau). Probiotik yang ditambahkan pada hijauan tidak membutuhkan dosis tinggi, cukup $0,5 \%$ berat hijauan yang akan diolah.

Hijauan yang telah dicacah disusun dalam silo yang terbuat dari karung plastic kapasitas $500 \mathrm{~kg}$ yang didesain khusus sebagai silo dan tong plastic kapasitas 60 liter. Karung terdiri dari 2 lapis, lapis dalam yang kedap udara dan lapisan luar yang tidak kedap udara (bahan karung urea). Proses penumpukan hijauan dalam silo harus betul-betul padat yang memungkinkan tidak ada udara yang bertahan di sela-sela tumpukan. Oleh karena itu diperlukan kerjasama diantara anggota kelompok ternak untuk menata tumpukan. Untuk melihat tanda silase sudah matang, setelah 2 minggu inkubasi dilakukan tes organoleptik memalui pengamatan warna, bau, serta $\mathrm{pH}$. Hasil pengamatan silase ditampilkan pada Tabel 4.

\section{Pengawetan Ampas Tahu}

Salah satu bahan pakan yang tidak awet untuk disimpan lama adalah ampas tahu. Ampas tahu merupakan limbah pengolahan tahu yang masih mengandung nutrisi cukup tinggi untuk ternak. Salah satu kekurangan ampas tahu sebagai bahan pakan adalah kandungan air yang sangat tinggi (80-84\%), sehingga tidak memungkinkan disimpan dalam jangka waktu lama. Oleh karena itu, pengawetan ampas tahu menggunakan probiotik asal limbah ternak dapat menjadi solusi peternak agar ampas tahu dapat digunakan dalam waktu yang lama pada kondisi banyak tersedia.

Ampas tahu yang akan diawetkan harus dicampur dengan bahan yang mempunyai kadar air rendah. Salah satu bahan pengikat air ampas tahu adalah dedak. Perbandingan kedua bahan dihitung agar campuran mempunya kadar air $\pm 55-60 \%$. Kadar air ini merupakan kadar air optimal agar mikroba probiotik dapat bekerja secara optimal. Perbandingan ampas tahu dan dedak padi pada kegiatan demplot adalah $70: 30$. Ampas tahu yang telah tercampur ditempatkan pada tong plastik kapasitas 30 Liter.

\section{Uji Palatabilitas Silase pada Ternak Domba}

Palatabilitas adalah respon yang diberikan oleh ternak terhadap pakan yang diberikan baik pada hewan ruminansia maupun pada ternak lainnya (Chruch dan Pond, 1988). Palatabilitas merupakan faktor yang sangat penting untuk menentukan tingkat konsumsi pakan. Palatabilitas ditentukan oleh rasa, bau, dan warna yang merupakan pengaruh faktor fisik dan kimia pakan (Kartadisastra, 1997; Parakkasi, 1999). Bahan pakan yang mempunyai palatabilitas tinggi akan dikonsumsi lebih banyak oleh ternak.

Setelah 2 minggu massa inkubasi anaerob, silase sudah menunjukkan kematangan dengan menunjukkan ciri-ciri silase yang baik yaitu warna hijau kecoklatan, bau aroma asam segar, tekstur padat, tidak lembek dan tidak berlendir, dan pH 4,3 (Kung dan Shaver, 2001). Tampilan silase yang dihasilkan anggota gapoktan terlihat baik (Tabel 4).

Pada saat uji coba silase pada ternak domba, terlihat respon domba yang dengan cepat mampu beradaptasi dengan pakan yang tidak biasa mereka konsumsi Pada perubahan bahan pakan yang diberikan, biasanya ternak domba akan melakukan adaptasi dulu, sehingga pemberian bahan pakan silase dilakukan secara bertahap. Dengan melihat respon ternak domba yang cepat mengkonsumsi silase yang diberikan menandakan silase ini mempunyai palatabilitas yang baik.

\section{SIMPULAN}

Peningkatan pengetahuan dan keterampilan peternak dapat dilihat dengan meningkatnya nilai post test. Partisipasi masyarakat peternak cukup baik, demikian juga partisipasi aparat termasuk babinsa dan petugas penyuluh pertanian lapangan (PPL) Kecamatan Sumedang Utara Kabupaten Sumedang cukup baik sehingga diharapkan menularkan semangat transfer teknologi tepat guna yang lebih luas lagi. Diperlukan keterlibatan masyarakat usia muda yang tergabung dalam wadah karang taruna untuk transformasi ilmu dan inovasi yang lebih baik.

\section{DAFTAR PUSTAKA}

Balai Penelitian dan Pengembangan Pertanian. 2003. Karakteristik Organoleptik Silase Rumpur Gajah (Pennisetum purpureum) akibat Penambahan Kultur Mikroba Campuran, Jawa Tengah. 
Bolsen dan Sapienza. 1993. Teknologi Silase: Penanaman, pembuatan dan pemberiannya pada ternak. Penerjemah Riri BS. Martoyoedo. Kansas. Dioneer Seeds.

Bolsen, K.K., Ashbell, G., Wilkinson, JM. 2000. Silage additives. In: Biotechnology in animal feeds and animal feeding. Editor: Wallace RJ, Chesson A. Weinheim. New York. Basel. Cambridge. Tokyo.

Direktorat Pemberdayaan Masyarakat Desa Departemen Dalam Negeri, 2014. Monografi Desa Rancamulya Kecamatan Sumedang Utara Kabupaten Sumedang.

Kartadisastra. 1997. Teknologi Bioenergi, PT. Agro Media Pustaka. Bogor.

Kung, L and R. Shaver. 2001. Interpretation and use of silase fermentation analysis reports. Wisconsin Team Forage. Focus on Forage, Vol. 3: no. 13. p. $1-4$.

Lionberger, H.F. dan P.H. Gwin. 1982. Communication strategies: a guide for agricultural change agents. Interstate Printers \& Publishers.

Moran J.P. and Trowen, 1995. The Effect of Feeding Silage treated with an inoculum of lactobacillus plantarum on Beef Production from Growing mld Finishing Cattle. Almales de Zooteclnie, AZOOA, 44 (Suppl):383.

Utomo, R. 2012. Teknologi Pakan Hijauan. Fakultas Peternakan, Universitas Gajah Mada, Yogyakarta.

Parakassi, A. 1999. IlmuNutrisi dan Makanan Ternak Ruminansia. Universitas Indonesia Press, Jakarta.

Rice, D.W, B.R Harman and M.A Hinds. 1995. Effect of Microbial Inoculation on the Nutritive Valve of GrassSilage. Annales de Zootechnie, AZOOA, 44 (Suppl 1):79.
Sutanto, H. 2000. MasalahGizi dan Produktivitas Ternak Ruminansia di Indonesia. Universitas Brawijaya Malang.

Schroeder, J.W. 2004. Silage Fermentation and Preservation. Extension Diry Specialist. AS-1254.

Tamada, J.H. Yokata, M. Ohshima and M. Tamaki. 1999. Effect of Additives, Storage Temperature and Regional Difference of Ensiling on the Fermentation Quality of Napier Grass (Pennisetum purpureum Schum.). Silage. AJAS, 12(1):28-35.

Thalib, A. J. Bestari. Y. Widiawati, H. Hamid. D. Suherman. 2000. Pengaruh Perlakuan Silase Jerami Padi dengan Mikroba Rumen Kerbau terhadap Daya Cerna dan Ekosistem Rumen Sapi. Jurnal Ilmu Ternak dan Veteriner 5(1):1-6.

Marlina, E.T., Tb. B. A. Kurnani, Y.A. Hidayati, D.Z. Badruzzaman, A. Firman. 2016. Detection of Pathogenic Bacteria and Heavy Metal on Liquid Organic Fertilizer from Dairy Cattle Waste. Proceeding of International Seminar on Livestock Production and Veterinary Technology. Denpasar Bali, Indonesia, August 10-12, 2016.

Hadipernata, M., W. Supartono dan M.A.F. Falah. 2012. Proses stabilisasi dedak padi (Oryza sativa L) menggunakan radiasi far infra red (FIR) sebagai bahan baku minyak pangan. Jurnal Aplikasi Teknologi Pangan 1 (4): 103-107. Bogor.

McDonald, A.R. Henderson, and S.J.E. Heron. 1991. The Biochemistry of Silage (Second Edition). Marlow, Bucks, UK: Chalcombe Publications.

Winarno, F.G. 2004. Kimia Pangan dan Gizi. Gramedia Pustaka Utama. Jakarta. 